\title{
Additional Evidence for Neuropsychiatric Manifestations in Mosaic Trisomy 20: A Case Report and Brief Review
}

\author{
Marco Colizzi ${ }^{1,2,3, *(D)}$, Giulia Antolini ${ }^{1}$, Laura Passarella ${ }^{1}$, Valentina Rizzo ${ }^{1}$, Elena Puttini ${ }^{1}$ \\ and Leonardo Zoccante ${ }^{1}$ \\ 1 Child and Adolescent Neuropsychiatry Unit, Maternal-Child Integrated Care Department, \\ Integrated University Hospital of Verona, 37126 Verona, Italy; giuliaantolini11@gmail.com (G.A.); \\ laura.passarella17@gmail.com (L.P.); valentinaannarizzo@gmail.com (V.R.); elena.puttini@aovr.veneto.it (E.P.); \\ leonardo.zoccante@aovr.veneto.it (L.Z.) \\ 2 Section of Psychiatry, Department of Neurosciences, Biomedicine and Movement Sciences, \\ University of Verona, 37134 Verona, Italy \\ 3 Department of Psychosis Studies, Institute of Psychiatry, Psychology and Neuroscience, \\ King's College London, London SE5 8AF, UK \\ * Correspondence: marco.colizzi@univr.it; Tel.: +39-045-812-6832
}

check for updates

Citation: Colizzi, M.; Antolini, G.; Passarella, L.; Rizzo, V.; Puttini, E.; Zoccante, L. Additional Evidence for Neuropsychiatric Manifestations in Mosaic Trisomy 20: A Case Report and Brief Review. Children 2021, 8 , 1030. https://doi.org/10.3390/ children 8111030

Academic Editor: Matteo

Alessio Chiappedi

Received: 21 September 2021

Accepted: 8 November 2021

Published: 10 November 2021

Publisher's Note: MDPI stays neutral with regard to jurisdictional claims in published maps and institutional affiliations.

Copyright: (c) 2021 by the authors. Licensee MDPI, Basel, Switzerland. This article is an open access article distributed under the terms and conditions of the Creative Commons Attribution (CC BY) license (https:/ / creativecommons.org/licenses/by/ $4.0 /)$.

\begin{abstract}
Mosaic trisomy 20 is a genetic condition in which three chromosomes 20 are found in some cells. Its clinical phenotype seems to be highly variable, with most features not reported across all individuals and not considered pathognomonic of the condition. Limited and recent evidence indicates that neuropsychiatric manifestations may be more present in the context of trisomy 20 than was once thought. Here, we present a case of a 14-year-old female adolescent of White/Caucasian ethnicity with mosaic trisomy 20, who was admitted twice to an inpatient Child and Adolescent Neuropsychiatry Unit for persisting self-injury and suicidal ideation. A severe and complex neuropsychiatric presentation emerged at the cognitive, emotional, and behavioral levels, including mild neurodevelopmental issues, isolation, socio-relational difficulties, depressed mood, temper outbursts, irritability, low self-esteem, lack of interest, social anxiety, panic attacks, self-cutting, and low-average-range and heterogeneous intelligence quotient profile. Particularly, the patient was considered at high risk of causing harm, mainly to self, and appeared to be only partially responsive to medication, even when polypharmacy was attempted to improve clinical response. Except for school bullying, no other severe environmental risk factors were present in the patient's history. The patient received a diagnosis of disruptive mood dysregulation disorder.
\end{abstract}

Keywords: pediatric conditions; psychiatric genetics; anger; self-regulation; aneuploidy; autosomal trisomy

\section{Introduction}

Aneuploidy in natural conception is an estimated $0.3 \%$ [1], with 0.6 per 10,000 births presenting a rare mosaic trisomy [2] and trisomy 20 accounting for $16 \%$ of all mosaicisms [3]. Trisomy 20 is a genetic condition caused by an extra chromosome at position 20 . While complete trisomy 20 is rare and suggested not to be compatible with life, a mosaic form of trisomy 20, where three chromosomes 20 are found only in some cells, may be possible, and thought to result in a grossly normal phenotype in most of the cases [4]. However, a recent review of the scientific literature revealed a paucity of studies reporting the phenotypic manifestations potentially associated with the condition [5]. To date, the clinical phenotype of trisomy 20 seems to be highly variable. In fact, most features are not reported across all individuals and are not considered pathognomonic of the condition, as they are also found in the general population, although at a lower rate [4]. More specifically, a number of craniofacial [4,6-13], cutaneous [11,14,15], cardiovascular-pulmonary [7,16-19], gastrointestinal [20], endocrinological [15], reproductive [10,15], locomotor [4,7,13,16,20-22], nervous [4,10,14,19,21,23], and cognitive and mental $[4,7,13,15,18,20,22-25]$ features have been reported. 
Recent evidence indicates that neuropsychiatric manifestations may be more present in the context of trisomy 20 than was once thought, with also potential forensic implications [5]. So far, it has been suggested that children with trisomy 20 may present with social [20], emotional [20], and learning [20,22] deficits, as per altered neurodevelopment [20,24]. Less clear is the persistence of psychiatric and behavioral features through adolescence and early adulthood.

Here, we report the case of a 14-year-old female adolescent of White/Caucasian ethnicity with mosaic trisomy 20, who was admitted twice to the inpatient Child and Adolescent Neuropsychiatry Unit of the Integrated University Hospital of Verona for persisting self-injury and suicidal ideation. Such admissions followed a neuropsychiatric assessment in the community and a presentation to the Accident \& Emergency (A\&E) Department, respectively. These were her first presentations to a neuropsychiatric ward. Her developmental history, neuropsychiatric presentation at admission, diagnosis, and clinical evolution are presented in detail in the following sections.

\section{Case Report}

\subsection{Medical History}

A detailed medical history was obtained from the patient and her parents. She was raised by her mother and father and currently lives at home with both her parents and her only sibling, an older sister. Her family history is positive for depressive disorder in her paternal grandmother, obsessive-compulsive disorder symptoms in her mother, self-injury in her sister, motor tics (self-limited childhood tics, including eye-winking movements as well as hand and finger twitching/stretching) in her mother and sister, and epileptic manifestations in her sister, maternal aunt, and paternal second cousin. A family history of joint laxity and hernias was also reported. As the patient's sister was not considered to have a clinically detectable mosaicism, formal genetic testing has never been performed, also considering the difficulties of ascertaining low-level mosaicism where most cell lineages are not affected. A full pedigree providing a graphic depiction of the patient's family structure and medical history is reported in Figure 1.

She was born to term out of her parents' third pregnancy (the first ended in a spontaneous abortion). The pregnancy was uncomplicated, but amniocentesis, performed due to advanced maternal age, showed a karyotype of 47,XX +20/46,XX in 10 of 32 metaphases analyzed. Her Apgar score, birth weight, length, and head circumference were all within normal ranges. Successively performed abdominal ultrasound and transfontanelle ultrasonography turned out negative. Overall, her development milestones proceeded regularly and on time, except for a slight delay in gross and fine motor skills. Starting from the pediatric age, physical examination findings related to her genetic condition included a broad and depressed nasal bone, low-set ears, hypotonia, and joint laxity. Physiatric assessment also highlighted the presence of flatfoot, a slight degree of shoulders asymmetry, and left convex scoliosis. During the years of primary school, facial tics and compulsive repetitive behaviors made their first appearance, together with the findings of a slight degree of dysgraphia and astigmatism. In secondary school, following episodes of bullying and cyberbullying, a progressive decline in her school performance was observed, along with the tendency to isolate herself from others, with difficulties in building relationships with peers, resulting in a poor friendship network. Furthermore, a continuous depressed mood throughout the day, associated with temper outbursts and irritability (in the absence of clear mood swings), low self-esteem, a lack of interest in any activity, significant social anxiety, panic attacks, daily episodes of self-cutting (occurring both at school and at home), and suicidal ideation were reported. Such symptoms did not appear to negatively affect the sleep-wake cycle. 


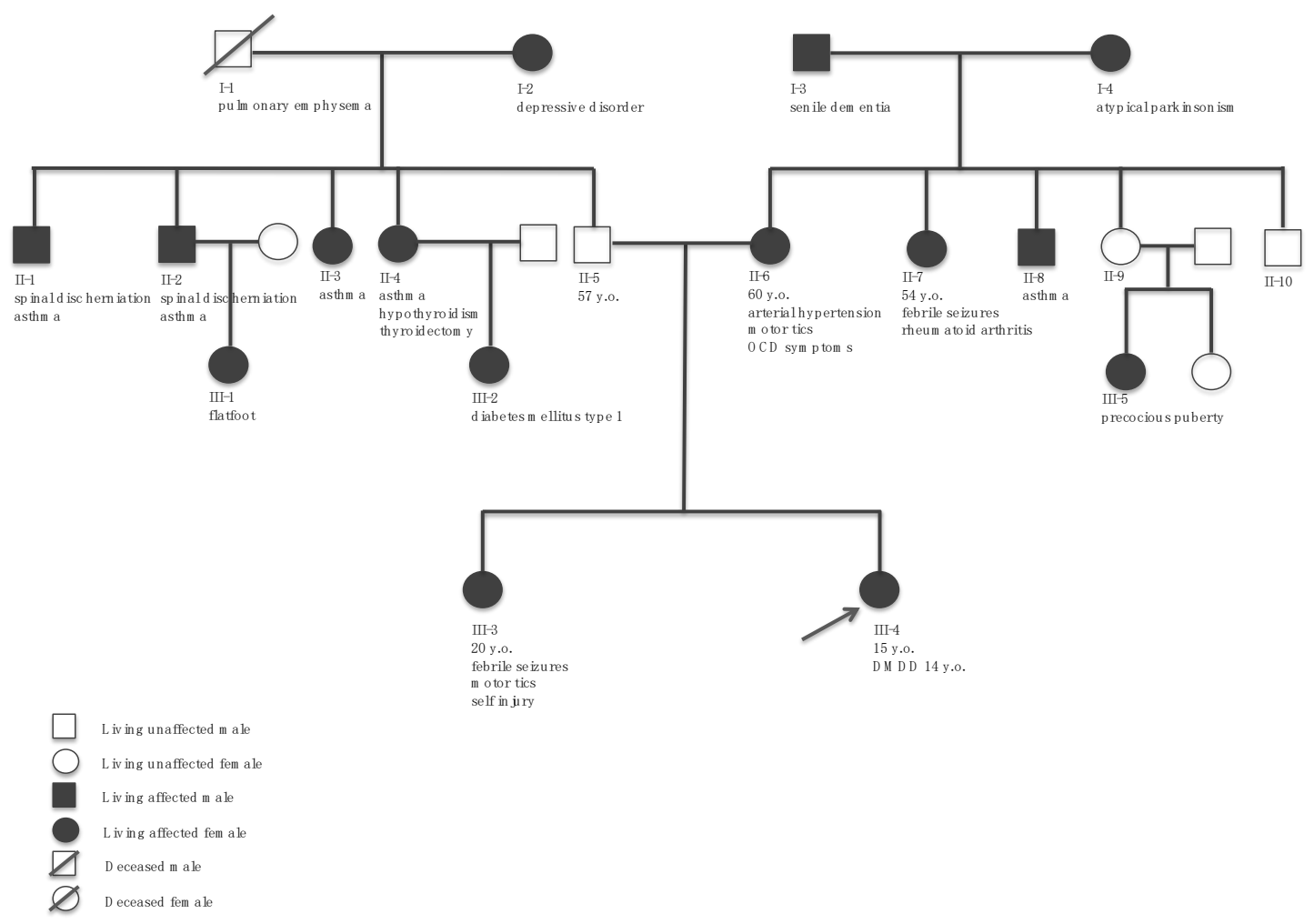

Figure 1. Pedigree of the patient. DMDD, disruptive mood dysregulation disorder.

Due to her neuropsychiatric distress, the patient was referred to the Childhood Neuropsychiatry Territorial Service, where a psychotherapeutic intervention was implemented, along with pharmacological treatment consisting of sertraline oral solution $20 \mathrm{mg} / \mathrm{mL}$, at a dosage of $1.25 \mathrm{~mL}$ per day, and alprazolam $0.75 \mathrm{mg} / \mathrm{mL}$ oral concentrate, at a dosage of $0.125 \mathrm{mg}$ per day (5 drops). Such therapy did not bring any benefit to the patient. Therefore, it was decided to admit her to the inpatient Child and Adolescent Neuropsychiatry Unit.

\subsection{Clinical Course, Diagnostic Conclusions, and Outpatient Follow-Up}

During hospitalization, she maintained overall good health and the following clinical evaluations were performed, aimed at monitoring her at both the clinical and the therapeutic level: COVID-19 nasal swab testing prior to admission, routine blood exams, urinalysis, and electrocardiogram; all of these turned out negative. Based on preexisting documentation and direct clinical observation, information was gathered with reference to her trisomy 20 manifestations. A detailed report of signs and symptoms, as contrasted to what is to be expected based on the current literature, is provided in Table 1.

Table 1. Trisomy 20 manifestations in the current case as compared to the previous literature.

Body Systems and Functions

Symptoms/Signs

Current Case

+ Present

$X$ Not Present

Craniofacial

\begin{tabular}{ccc}
\hline Korkontzelos (2017) [6], Velissariou et al. (2002) [7] & Underdeveloped nasal bone & + \\
\hline $\begin{array}{c}\text { Hsu et al. (1991) [4], Mavromatidis et al. (2010) [8], } \\
\text { Myers and Prouty (1989) [9], Ensenauer et al. (2005) [10] }\end{array}$ & Ear morphology abnormalities & + \\
\hline Velissariou et al. (2002) [7], Warren et al. (2001) [11] & Micrognathia and retrognathia & $X$ \\
\hline Stromme et al. (2005) [12] & Cleft lip and palate & $X$ \\
\hline
\end{tabular}


Table 1. Cont.

Body Systems and Functions

Symptoms/Signs

Current Case

+ Present

$X$ Not Present

Hsu et al. (1991) [4], Velissariou et al. (2002) [7], Reish et al. (1998) [13]

Abnormal periorbital region morphology

$X$

Cutaneous

Powis and Erickson (2009) [14]

Warren et al. (2001) [11], Powis and Erickson (2009) [14], Girard et al. (2005) [15]

Hartmann et al. (2004) [18]

Velissariou et al. (2002) [7]

Thin and brittle nails

$X$

Hypomelanosis of Ito

$X$

Cardiovascular-Pulmonary

Morales et al. (2010) [16]

Pulmonary isomerism

Congenital heart defects

Linear and whorled nevoid hypermelanosis

Mongolian spots

$X$

$\mathrm{X}$

Vetissariou et al. (2002) [7], Karaoguz et al. (2007) [17],

Hartmann et al. (2004) [18], Hsieh et al. (1992) [19]

Gastrointestinal

Willis et al. (2008) [20]

Endocrinological

Girard et al. (2005) [15]

Growth hormone deficiency

Stipsis

$+$

Reproductive

Ensenauer et al. (2005) [10], Girard et al. (2005) [15]

Cryptorchidism

$X$

Locomotor

Willis et al. (2008) [20], Stein et al. (2008) [21]

Sloped shoulders

Velissariou et al. (2002) [7], Willis et al. (2008) [20]

Velissariou et al. (2002) [7], Reish et al. (1998) [13], Willis

et al. (2008) [20], Stein et al. (2008) [21], Holzgreve et al. (1986) [22]

Velissariou et al. (2002) [7]

Morales et al. (2010) [16]

Abnormal spinal column morphology

$+($ Scoliosis $)$

Central and peripheral altered muscle tone $\quad+$ (Hypotonia)

Hsu et al. (1991) [4], Velissariou et al. (2002) [7]

Montplaisir (2019) [5]

Stein et al. (2008) [21]

Ligamentous laxity $\quad+$

Camptodactyly $\quad \mathrm{X}$

Clinodactyly

$\mathrm{X}$

Polydactyly

$\mathrm{X}$

Rib anomalies

$X$

$X$

Nervous

Powis and Erickson (2009) [14]

Ensenauer et al. (2005) [10]

Hsu et al. (1991) [4], Salafsky et al. (2001) [23]

Hsieh et al. (1992) [19], Stein et al. (2008) [21]

Cognitive and Mental

Willis et al. (2008) [20]

Repetitive behaviors

\begin{tabular}{cl} 
Epileptic manifestations & $\mathrm{X}$ \\
\hline Hearing impairment & $\mathrm{X}$ \\
\hline Microcephaly & $\mathrm{X}$ \\
\hline bnormal neuroimaging findings & $\mathrm{X}$ \\
\hline
\end{tabular}

Preserved IQ and learning disabilities

$+$

Isolation

$+$

Social and emotional difficulties

Pragmatic/Social communication difficulties

+
$x$
$x$
$x$
$x$
$x$
$x$
$x$
$x$
+
+
+
+


Table 1. Cont.

\begin{tabular}{ccc}
\hline Body Systems and Functions & Symptoms/Signs & $\begin{array}{c}\text { Current Case } \\
+ \text { Present } \\
\text { X Not Present }\end{array}$ \\
\hline Wallerstein et al. (2005) [24] & $\begin{array}{c}\text { Atypical neurodevelopment with } \\
\text { attention deficit }\end{array}$ \\
\cline { 2 - 3 } & Impulsivity & + \\
\hline $\begin{array}{c}\text { Hsu et al. (1991) [4], Velissariou et al. (2002) [7], Girard et al. } \\
\text { (2005) [15], Hartmann et al. (2004) [18], Salafsky et al. (2001) } \\
\text { [23], Miny et al. (1989) [25] }\end{array}$ & Developmental psychomotor difficulties \\
\hline Reish et al. (1998) [13] & Speech difficulties \\
\hline Holzgreve et al. (1986) [22] & Impaired fine and gross motor abilities \\
\hline Montplaisir (2019) [5] & Developmental language difficulties \\
\hline Montplaisir (2019) [5] & Self-injury & + \\
\hline
\end{tabular}

A psychological assessment was also carried out using the Child Behavior Checklist (CBCL) 6-18 [26] compiled by both the patient and her mother, who was with her throughout the hospitalization. CBCL subscales suggesting pathological symptoms (scores > 70) were "Anxious/Depressed", "Withdrawn/Depressed", "Social Problems", "Thought Problems", "Attention Problems", "Depressive Problems", "Anxiety Problems", "Sluggish Cognitive Tempo", and "Stress Problems". "Somatic Complaints" and "Obsessive-Compulsive Problems" were borderline symptoms according to her mother, while being rated as pathological by the patient (Table 2).

Throughout her hospital stay, the patient remained disheveled and unkempt. Selfcutting injuries were evident on her hands and neck, and upon further examination, they covered most of the forearms and thighs. The injuries were shallow and appeared to be in multiple stages of healing. She wore loose-fitting clothing, mostly in black. During interviews, she spoke reticently and only after requesting that her mother left the room. She appeared tense and had difficulty sustaining eye contact. Her speech was scarce, low in volume, and lacking modulation. She only answered questions when prodded, and her replies lacked articulation. She was coherent and oriented to person, place, and time. There were no signs of perceptual abnormalities. Hallucinations, depersonalization, derealization, and dissociative phenomena were denied. The patient did not show any loosening of association, flight of ideas, tangentiality, or circumstantiality. Her affect was flat but not inappropriate to the content of her speech, which was focused on the circumstances of her hospitalization, her emotional malaise, and her continued self-harm ideation. Some anxiety through repetitive wringing of her hands was observed. She reported that she had no appetite but had no trouble sleeping at night.

Considering the suboptimal symptom control, a change in pharmacological treatment was made. In particular, sertraline and alprazolam were discontinued, whereas pregabalin at a dosage of $150 \mathrm{mg}$, fluvoxamine at a dosage of $50 \mathrm{mg}$, and quetiapine extended release at a dosage of $50 \mathrm{mg}$ were initiated. The patient received a diagnosis of disruptive mood dysregulation disorder (DMDD), according to the Diagnostic and Statistical Manual of Mental Disorders, -Fifth Edition DSM-5 [27], and was discharged 7 days later in good clinical condition, with the indication to continue the treatment with pregabalin, fluvoxamine, and quetiapine. 
Table 2. Neurocognitive and psychological assessment.

\begin{tabular}{|c|c|}
\hline \multicolumn{2}{|r|}{ Neurocognitive Assessment } \\
\hline Wechsler Intelligence Scale for & Score \\
\hline Children-Fourth Edition (WISC-IV) & (95\% Confidence Interval; subtest raw score) \\
\hline Full-Scale Intelligence Quotient & $\begin{array}{c}80 \\
(75-87)\end{array}$ \\
\hline Verbal Comprehension & $\begin{array}{c}78 \\
\text { (72-86; Similarities: 7; Comprehension: 3; Vocabulary: 7; } \\
\text { Information (supplemental subtest): 5) }\end{array}$ \\
\hline Perceptual Reasoning & $\begin{array}{c}95 \\
\text { (87-103; Block Design: 11; Matrix Reasoning: 9; Picture Concepts: 8) } \\
79\end{array}$ \\
\hline Working Memory & $\begin{array}{c}\text { (72-90; Subtest: Digit Span: 7; Letter-Number Sequencing: 6; } \\
\text { Arithmetic (supplemental subtest): 3) }\end{array}$ \\
\hline Processing Speed & $\begin{array}{c}85 \\
\text { (77-97; Coding: 8; Symbol Search: 7) }\end{array}$ \\
\hline
\end{tabular}

\begin{tabular}{|c|c|c|c|}
\hline \multicolumn{4}{|c|}{ Psychological Assessment } \\
\hline Child Behavior Checklist (CBCL) & T-Scores (Patient) & T-Scores (Mother) & $\begin{array}{c}\text { Clinical: } \mathrm{T} \geq 70 \\
\text { Borderline: } 65 \geq \mathrm{T}<70 \\
\text { Non-clinical: } \mathrm{T}<65\end{array}$ \\
\hline \multicolumn{4}{|l|}{ Syndrome Scale Scores } \\
\hline Social Problems & 70 & 70 & Clinical \\
\hline Thought Problems & 73 & 73 & Clinical \\
\hline Attention Problems & 83 & 70 & Clinical \\
\hline \multicolumn{4}{|l|}{ Internalizing Problems } \\
\hline Withdrawn/Depressed & 100 & 100 & Clinical \\
\hline Anxious/Depressed & 100 & 74 & Clinical \\
\hline Somatic Complaints & 70 & 65 & Clinical/Borderline \\
\hline \multicolumn{4}{|l|}{ Externalizing Problems } \\
\hline Rule-Breaking Behavior & 60 & 57 & Non-clinical \\
\hline Aggressive Behavior & 58 & 58 & Non-clinical \\
\hline \multicolumn{4}{|l|}{ Total Problems } \\
\hline Internalizing Score & 86 & 77 & Clinical \\
\hline Externalizing Score & 59 & 58 & Non-clinical \\
\hline Total Problems Score & 74 & 70 & Clinical \\
\hline \multicolumn{4}{|l|}{ DSM-Oriented Scales } \\
\hline Depressive Problems & 88 & 79 & Clinical \\
\hline Anxiety Problems & 94 & 73 & Clinical \\
\hline Somatic Problems & 59 & 59 & Non-clinical \\
\hline Attention Deficit & 69 & 60 & Borderline/Non-clinical \\
\hline Oppositional Defiant Problems & 59 & 63 & Non-clinical \\
\hline Conduct Problems & 61 & 55 & Non-clinical \\
\hline \multicolumn{4}{|l|}{ Other Scales } \\
\hline Sluggish Cognitive Tempo & 80 & 73 & Clinical \\
\hline Obsessive-Compulsive Problems & 87 & 66 & Clinical/Borderline \\
\hline Stress Problems & 86 & 78 & Clinical \\
\hline
\end{tabular}

At a follow-up visit, planned 1 week later, the patient presented with symptoms of a potential relapse. Thus, the dosages of fluvoxamine and quetiapine extended release were increased to $75 \mathrm{mg}$ and $150 \mathrm{mg}$, respectively. However, after 1 more week, she entered the A\&E Department presenting with the same symptoms she had when she was admitted for the first time, namely remarkable social anxiety and panic attacks, significantly low mood, daily episodes of self-injury, and suicidal ideation. Using a pencil sharpener blade, she had cut her forearms, abdomen, and legs, to the point where she had carved the word "help" into the skin of her left thigh. The neuropsychiatrist assessment advised for another hospitalization, and she was hence admitted after a negative COVID-19 nasal swab. Besides multiple routine blood exams and electrocardiograms, all of which turned out negative, 
this time a plastic surgical evaluation and a cardiological assessment with color-Doppler ultrasound were also performed, which showed nothing pathological.

Despite the initial improvement, as the pharmacological treatment had not led to clinical stability, it was modified as follows: pregabalin and quetiapine were discontinued, whereas lithium prolonged release at a dosage of $166 \mathrm{mg}$ per day and olanzapine at a dosage of $10 \mathrm{mg}$ per day were introduced. Moreover, the fluvoxamine dosage was increased to $150 \mathrm{mg}$. The previous diagnosis of disruptive mood dysregulation disorder (DMDD), according to DSM-5, was confirmed, and she was discharged 13 days later in good overall clinical condition, with the indication to continue the treatment with lithium prolonged release, fluvoxamine, and olanzapine.

A post-discharge assessment performed 2 weeks later found the patient overall clinically stable but only partially responsive to treatment. Despite improvement, her mood was still oriented toward depression and socio-emotional difficulties were still reported, resulting in outbursts and irritability. An abdominal ultrasound was also performed, which turned out negative, with liver, hepatic ducts, portal vein, gallbladder, kidneys, spleen, pancreas, and bladder all normal in appearance and echotexture. Furthermore, after about 4 weeks of pharmacological treatment stability, a neurocognitive assessment was performed using the Wechsler Intelligence Scale for Children-Fourth Edition (WISC-IV) [28]. The patient's full-scale intelligence quotient (FSIQ) was in the low average range as for normative data $(F S I Q=80)$, and a heterogeneous profile emerged, with "Perceptual Reasoning" falling in the average range, "Processing Speed" in the low average range, and "Verbal Comprehension" and "Working Memory" in the very low range (Table 2).

\section{Discussion}

The past decades have witnessed an increasing interest in the role of genetics in shaping human behavior. Genome-wide association studies (GWASs) have helped detect the polygenic architecture of psychiatric disorders, with potential applications in clinical settings [29]. Disruptive mood dysregulation disorder (DMDD) is no exception. Since its introduction in the DSM-5 [27], studies have investigated the role of genetics in modulating emotional and behavioral functioning in youth suffering from the condition. Research interest has focused on genetic variation affecting the function of neurobiological systems, such as the opioid system, that are known to modulate cognitive, emotional, and social behaviors [30]. In addition, studies support developmentally dynamic genetic effects on core features of the disorder, such as irritability, with genetic influences being higher in the female gender and as compared to environmental features [31]. However, the environment is still believed to exert a modulatory effect [32]. Consistently, evidence from gene-by-environment-interaction studies suggests that genetic variation in the hypothalamic-pituitary-adrenal (HPA) axis may interact with the effect of chronic stress in increasing the risk of presenting with a negative affect [33]. The latter is considered one of the factors predicting later psychopathology [34] as well as stability of DMDD symptoms, such as an irritable-angry mood and temper outbursts, through adolescence and early adulthood.

The first linkage study of psychosis using empirically derived, clinically homogeneous phenotypes, defined by symptomatic profiles rather than operationalized diagnostic criteria, revealed an unexpected linkage to chromosome 20 for "Schizomania" and "Mania" latent classes of psychotic illness as well as the highest logarithm of the odds (LOD) score of any latent class in the genome for the "Deficit Syndrome" class [35]. That chromosome 20 may be involved in both manic/positive and depressive/negative symptoms of psychosis is supported by genome scan studies and meta-analyses finding evidence of linkage for bipolar disorder and schizophrenia [35-40], as well as a comprehensive gene-based association study of 327 genes on chromosome 20, identifying two loci, R3HDML and C20orf39, associated with depressive symptoms in psychotic illness [41]. Taken together, these studies are compelling in their support of chromosome 20 harboring genes relevant to the affective component of schizophrenia and conditions presenting with admixtures 
of mood and psychotic symptoms [42]. Further, chromosome 20 has been associated with affective psychoses characterized by suicidal attempts [40], and a recent genome-wide association study identified a number of single-nucleotide polymorphisms (SNPs), all on chromosome 20, supporting a genetic transmission of suicide attempts, not entirely accounted for by suffering from a mental disorder [43]. Interestingly, functional SNPs on chromosome 20 influencing gene expression and bipolar disorder susceptibility have been shown to modulate hippocampal volume and cognitive performance in healthy individuals [44].

Along with numerical chromosome anomalies, such as mosaicism, structural anomalies of the chromosome 20, including ring chromosome [45], deletion of the short arm [46], microduplication within the short arm [47], and microdeleletion of the long arm [48], have also been associated with alterations in several body systems and functions as well as neurocognitive difficulties and neuropsychiatric features. Commonly reported behavioral manifestations include developmental delay, intellectual disability, sensory processing disorder, poor motor coordination, impaired speech and executive abilities, apathy or hyperactivity, loss of social skills and poor emotional regulation, obsessive behavior, psychosis, and autistic features.

Of further interest, the activity-dependent neuroprotective protein (ADNP) syndrome, which was only discovered in 2014 , is a neurodevelopmental genetic disorder caused by changes (mostly de novo mutations) in the ADNP gene, which is located on the long arm of chromosome 20. It is frequently associated with developmental delays, intellectual delays, motor planning delays, delayed or absent speech, and autism features of varying degrees [49]. A potential role in self-injurious behavior has also been suggested [50]. Multiple body systems may be affected, including the brain (e.g., developmental delay, intellectual disability), heart (e.g., atrial septal defect, patent ductus arteriosus), immune system (e.g., frequent infections), gastrointestinal system (e.g., gastroesophageal reflux, constipation), endocrine system (e.g., early puberty, thyroid hormone problems), and musculoskeletal system (e.g., joint hypermobility, scoliosis) [49]. Finally, several pathogenic and possibly pathogenic variants in the coding region of the prion protein gene (PRNP), which is also located on chromosome 20 , have been associated with different clinical phenotypes of neurodegenerative diseases, including Creutzfeldt-Jakob disease, Gerstmann-StraüsslerScheinker disease, fatal familial insomnia, and other types of dementia [51].

In summary, increasing evidence from studies of the numerical and structural variation of the genome at the chromosomal and subchromosomal levels supports a role of chromosome 20 in the manifestation of a wide range of neuropsychiatric features. A recent case report on a young adult male individual with trisomy 20 reported some novel neuropsychiatric symptoms that had never been associated with the condition, such as childhood-onset visual hallucinations and self-injury, including biting self and headbanging, hypothesizing an underestimation of the extent of mental disorders in the context of trisomy 20 [5]. In addition, authors suggested that several environmental risk factors encountered in their case, such as child abuse, family discord, and exposure to domestic violence, may have at least partially accounted for the unusually severe psychiatric presentation as compared to previously reported cases, where, instead, milder or subthreshold psychiatric symptoms may have been overlooked [5]. Noteworthy, in that case, trisomy 20 was successfully applied as a mitigating factor in a capital murder trial [5].

The current trisomy 20 case revealed a severe and complex neuropsychiatric presentation at the cognitive, emotional, and behavioral levels. In addition, the patient was considered at high risk of causing harm, mainly to self, and appeared to be only partially responsive to medication, even when polypharmacy was attempted to improve clinical response. To the best of our knowledge, except for school bullying and the potentially stressful impact of the sister's self-harm, no other severe environmental risk factors were present in the patient's history.

Due to mosaicism, a remarkable variability in clinical symptoms between cases is not surprising. It is plausible to hypothesize that depending on the degree of mosaicism, body 
systems may be differentially affected, with implications for the severity of the phenotypic expression. Further, the potential correlation between the level of trisomic cells and clinical outcome is currently unknown and deserves investigation, as for other chromosomal mosaicisms [52]. In fact, it is likely that patients with trisomy 20 presenting with more evident neuropsychiatric distress have a higher percentage of affected cells in the brain as well as systems other than the central nervous system (CNS), such as the immune, cardiometabolic, and hypothalamic-pituitary-adrenal (HPA) systems, which have been involved in the onset of major psychiatric disorders [53].

Author Contributions: Conceptualization, M.C., G.A., L.P., V.R., E.P. and L.Z.; methodology, M.C., G.A., L.P., V.R., E.P. and L.Z.; validation, M.C., G.A., L.P., V.R., E.P. and L.Z.; investigation, M.C., G.A., L.P., V.R., E.P. and L.Z.; resources, M.C., G.A., L.P., V.R., E.P. and L.Z.; data curation, M.C., G.A., L.P., V.R., E.P. and L.Z.; writing-original draft preparation, M.C., G.A., L.P., V.R. and E.P.; writing-review and editing, M.C., G.A., L.P., V.R., E.P. and L.Z.; visualization, M.C., G.A., L.P., V.R., E.P. and L.Z.; supervision, M.C. and L.Z. All authors have read and agreed to the published version of the manuscript.

Funding: This research received no external funding.

Institutional Review Board Statement: The study was conducted according to the guidelines of the Declaration of Helsinki, and ethical approval was not required.

Informed Consent Statement: The patient and her parents agreed to this publication by written consent.

Data Availability Statement: The data reported in this paper are available from the medical history of the patient.

Acknowledgments: The authors would like to acknowledge infrastructure from the Integrated University Hospital of Verona and the University of Verona.

Conflicts of Interest: M.C. has been a consultant/advisor to GW Pharma Limited and F. HoffmannLa Roche Limited, outside of this work. All the other authors declare no conflict of interest.

\section{References}

1. Chuang, T.-H.; Chang, Y.-P.; Lee, M.-J.; Wang, H.-L.; Lai, H.-H.; Chen, S.-U. The Incidence of Mosaicism for Individual Chromosome in Human Blastocysts Is Correlated with Chromosome Length. Front. Genet. 2021, 11, 1677. [CrossRef]

2. Pertile, M.D. Genome-Wide Cell-Free DNA-Based Prenatal Testing for Rare Autosomal Trisomies and Subchromosomal Abnormalities. In Noninvasive Prenatal Testing (NIPT); Page-Christiaens, L., Klein, H.-G., Eds.; Academic Press: Cambridge, MA, USA, 2018; pp. 97-123.

3. Hsu, L.Y.F.; Kaffe, S.; Perlis, T.E. Trisomy 20 mosaicism in prenatal diagnosis-a review and update. Prenat. Diagn. 1987, 7, 581-596. [CrossRef] [PubMed]

4. Hsu, L.Y.F.; Kaffe, S.; Perlis, T.E. A revisit of trisomy 20 mosaicism in prenatal diagnosis-An overview of 103 cases. Prenat. Diagn. 1991, 11, 7-15. [CrossRef] [PubMed]

5. Montplaisir, R.; Lee, E.; Moreno-De-Luca, D.; Myers, W.C. Mosaic trisomy 20 and mitigation in capital crimes sentencing: A review and case report. Behav. Sci. Law 2019, 37, 512-521. [CrossRef] [PubMed]

6. Korkontzelos, I. Prenatal diagnosis of trisomy 20 mosaicism associated with hypoplastic nasal bone as a single sonographic marker. Eur. J. Obstet. Gynecol. Reprod. Biol. 2017, 213, 140-141. [CrossRef]

7. Velissariou, V.; Antoniadi, T.; Gyftodimou, J.; Bakou, K.; Grigoriadou, M.; Christopoulou, S.; Hatzipouliou, A.; Donoghue, J.; Karatzis, P.; Katsarou, E.; et al. Maternal uniparental isodisomy 20 in a foetus with trisomy 20 mosaicism: Clinical, cytogenetic and molecular analysis. Eur. J. Hum. Genet. 2002, 10, 694-698. [CrossRef] [PubMed]

8. Mavromatidis, G.; Dinas, K.; Delkos, D.; Vosnakis, C.; Mamopoulos, A.; Rousso, D. Case of prenatally diagnosed non-mosaic trisomy 20 with minor abnormalities. J. Obstet. Gynaecol. Res. 2010, 36, 866-868. [CrossRef] [PubMed]

9. Myers, T.L.; Prouty, L.A. Non-mosaic trisomy 20 in amniotic fluid cultures with minor anomalies in the fetus. Clin. Genet. 2008, 35, 233-236. [CrossRef]

10. Ensenauer, R.E.; Shaughnessy, W.J.; Jalal, S.M.; Dawson, D.B.; Courteau, L.K.; Ellison, J.W. Trisomy 20 mosaicism caused by a maternal meiosis II error is associated with normal intellect but multiple congenital anomalies. Am. J. Med. Genet. Part A 2005, 134A, 202-206. [CrossRef]

11. Warren, N.; Soukup, S.; King, J.; Dignan, P. Prenatal diagnosis of trisomy 20 by chorionic villus sampling (CVS): A case report with long-term outcome. Prenat. Diagn. 2001, 21, 1111-1113. [CrossRef] 
12. Strømme, P.; Van Der Hagen, C.B.; Haakonsen, M.; Risberg, K.; Hennekam, R. Follow-up of a girl with cleft lip and palate and multiple malformations: Trisomy 20 mosaicism. Scand. J. Plast. Reconstr. Surg. Hand Surg. 2005, 39, 178-179. [CrossRef] [PubMed]

13. Reish, O.; Wolach, B.; Amiel, A.; Kedar, I.; Dolfin, T.; Fejgin, M. Dilemma of trisomy 20 mosaicism detected prenatally: Is it an innocent finding? Am. J. Med. Genet. 1998, 77, 72-75. [CrossRef]

14. Powis, Z.; Erickson, R.P. Uniparental disomy and the phenotype of mosaic trisomy 20: A new case and review of the literature. J. Appl. Genet. 2009, 50, 293-296. [CrossRef] [PubMed]

15. Girard, C.; Guillot, B.; Rivier, F.; Vale, F.D.; Bessis, D. Mosaïcisme pigmentaire de type Ito révélant une trisomie 20 en mosaïque. Ann. Dermatol. Venereol. 2005, 132, 151-153. [CrossRef]

16. Morales, C.; Cuatrecasas, E.; Mademont-Soler, I.; Clusellas, N.; Peruga, E.; Català, V.; Garrido, C.; Milà, M.; Soler, A.; Sánchez, A. Non-mosaic trisomy 20 of paternal origin in chorionic villus and amniotic fluid also detected in fetal blood and other tissues. Eur. J. Med. Genet. 2010, 53, 197-200. [CrossRef] [PubMed]

17. Karaoguz, M.Y.; Pala, E.; Kula, S.; Karaer, K.; Kan, D.; Nas, T.; Tunaoglu, S. Transposition of great arteries in an infant born after prenatal diagnosis of trisomy 20 mosaicism. Genet. Couns. 2007, 18, 437-443.

18. Hartmann, A.; Hofmann, U.B.; Hoehn, H.; Broecker, E.B.; Hamm, H. Postnatal Confirmation of Prenatally Diagnosed Trisomy 20 Mosaicism in a Patient with Linear and Whorled Nevoid Hypermelanosis. Pediatr. Dermatol. 2004, 21, 636-641. [CrossRef] [PubMed]

19. Hsieh, C.C.; Hsu, J.J.; Lo, L.M.; Hsieh, T.T.; Soong, Y.K. Non-mosaic trisomy 20 in cultures of amniotic fluid from a fetus with serious congenital malformation. J. Formos. Med. Assoc. 1992, 91, 543-544.

20. Willis, M.J.; Bird, L.M.; Dell'Aquilla, M.; Jones, M.C. Expanding the phenotype of mosaic trisomy 20. Am. J. Med. Genet. Part A 2008, 146A, 330-336. [CrossRef]

21. Stein, Q.P.; Boyle, J.G.; Crotwell, P.L.; Flanagan, J.D.; Johnson, K.J.; Davis-Keppen, L.; Van Eerden, P.; Woltanski, A.R.; Watson, W.J. Prenatally diagnosed trisomy 20 mosaicism associated with arachnoid cyst of basal cistern. Prenat. Diagn. 2008, 28, 1169-1170. [CrossRef]

22. Holzgreve, W.; Golabi, M.; Bradley, J. Multiple congenital anomalies in a child born after prenatal diagnosis of trisomy 20mosaicism. Clin. Genet. 1986, 29, 342-344. [CrossRef]

23. Salafsky, I.S.; MacGregor, S.N.; Claussen, U.; Von Eggeling, F. Maternal UPD 20 in an infant from a pregnancy with mosaic trisomy 20. Prenat. Diagn. 2001, 21, 860-863. [CrossRef] [PubMed]

24. Wallerstein, R.; Twersky, S.; Layman, P.; Kernaghan, L.; Aviv, H.; Pedro, H.F.; Pletcher, B. Long term follow-up of developmental delay in a child with prenatally-diagnosed trisomy 20 mosaicism. Am. J. Med. Genet. Part A 2005, 137A, 94-97. [CrossRef] [PubMed]

25. Miny, P.; Karabacak, Z.; Hammer, P.; Schulte-Vallentin, M.; Holzgreve, W. Chromosome Analyses from Urinary Sediment: Postnatal Confirmation of a Prenatally Diagnosed Trisomy 20 Mosaicism. N. Engl. J. Med. 1989, 320, 809. [CrossRef] [PubMed]

26. Achenbach, T.M.; Rescorla, L.A. Manual for the ASEBA School-Age Forms \& Profiles; University of Vermont Research Center for Children, Youth \& Families: Burlington, VT, USA, 2001.

27. APA. Diagnostic and Statistical Manual of Mental Disorders, 5th ed.; American Psychiatric Publishing: Arlington, TX, USA, 2013.

28. Wechsler, D. Wechsler Intelligence Scale for Children, 4th ed.; APA PsycNet: Washington, DC, USA, 2003.

29. Ikeda, M.; Saito, T.; Kanazawa, T.; Iwata, N. Polygenic risk score as clinical utility in psychiatry: A clinical viewpoint. J. Hum. Genet. 2020, 66, 53-60. [CrossRef] [PubMed]

30. Cimino, S.; Carola, V.; Cerniglia, L.; Bussone, S.; Bevilacqua, A.; Tambelli, R. The $\mu$-opioid receptor gene A118G polymorphism is associated with insecure attachment in children with disruptive mood regulation disorder and their mothers. Brain Behav. 2020, 10, e01659. [CrossRef]

31. Roberson-Nay, R.; Leibenluft, E.; Brotman, M.A.; Myers, J.; Larsson, H.; Lichtenstein, P.; Kendler, K.S. Longitudinal Stability of Genetic and Environmental Influences on Irritability: From Childhood to Young Adulthood. Am. J. Psychiatry 2015, 172, 657-664. [CrossRef]

32. Moore, A.A.; Lapato, D.M.; Brotman, M.A.; Leibenluft, E.; Aggen, S.H.; Hettema, J.M.; York, T.P.; Silberg, J.L.; Roberson-Nay, R. Heritability, stability, and prevalence of tonic and phasic irritability as indicators of disruptive mood dysregulation disorder. $J$. Child Psychol. Psychiatry 2019, 60, 1032-1041. [CrossRef]

33. Starr, L.R.; Dienes, K.; Li, Y.I.; Shaw, Z.A. Chronic stress exposure, diurnal cortisol slope, and implications for mood and fatigue: Moderation by multilocus HPA-Axis genetic variation. Psychoneuroendocrinology 2019, 100, 156-163. [CrossRef]

34. Dougherty, L.R.; Barrios, C.S.; Carlson, G.A.; Klein, D.N. Predictors of Later Psychopathology in Young Children with Disruptive Mood Dysregulation Disorder. J. Child Adolesc. Psychopharmacol. 2017, 27, 396-402. [CrossRef]

35. Arinami, T.; Ohtsuki, T.; Ishiguro, H.; Ujike, H.; Tanaka, Y.; Morita, Y.; Mineta, M.; Takeichi, M.; Yamada, S.; Imamura, A.; et al. Genomewide High-Density SNP Linkage Analysis of 236 Japanese Families Supports the Existence of Schizophrenia Susceptibility Loci on Chromosomes 1p, 14q, and 20p. Am. J. Hum. Genet. 2005, 77, 937-944. [CrossRef] [PubMed]

36. Detera-Wadleigh, S.D.; Badner, J.A.; Yoshikawa, T.; Sanders, A.R.; Goldin, L.R.; Turner, G.; Rollins, D.Y.; Moses, T.; Guroff, J.J.; Kazuba, D.; et al. Initial Genome Scan of the NIMH Genetics Initiative Bipolar Pedigrees: Chromosomes 4, 7, 9, 18, 19, 20, and 21q. Am. J. Med. Genet. 1997, 74, 254-262. [CrossRef] 
37. Lewis, C.; Levinson, D.F.; Wise, L.H.; DeLisi, L.E.; Straub, R.E.; Hovatta, I.; Williams, N.M.; Schwab, S.G.; Pulver, A.E.; Faraone, S.; et al. Genome Scan Meta-Analysis of Schizophrenia and Bipolar Disorder, Part II: Schizophrenia. Am. J. Hum. Genet. 2003, 73, 34-48. [CrossRef] [PubMed]

38. Moises, H.; Yang, L.; Kristbjarnarson, H.; Wiese, C.; Byerley, W.; Macciardi, F.; Arolt, V.; Blackwood, D.; Liu, X.; Sjögren, B.; et al. An international two-stage genome-wide search for schizophrenia susceptibility genes. Nat. Genet. 1995, 11, 321-324. [CrossRef]

39. Ross, J.; Berrettini, W.; Coryell, W.; Gershon, E.S.; Badner, J.A.; Kelsoe, J.R.; McInnis, M.G.; McMahon, F.; Murphy, D.L.; Nurnberger, J.; et al. Genome-wide parametric linkage analyses of 644 bipolar pedigrees suggest susceptibility loci at chromosomes 16 and 20. Psychiatr. Genet. 2008, 18, 191-198. [CrossRef] [PubMed]

40. Radhakrishna, U.; Senol, S.; Herken, H.; Gücüyener, K.; Gehrig, C.; Blouin, J.-L.; Akarsu, N.; Antonarakis, S. An apparently dominant bipolar affective disorder (BPAD) locus on chromosome 20p11.2-q11.2 in a large Turkish pedigree. Eur. J. Hum. Genet. 2001, 9, 39-44. [CrossRef]

41. Bigdeli, T.B.; Maher, B.S.; Zhao, Z.; Oord, E.J.C.G.V.D.; Thiselton, D.L.; Sun, J.; Webb, B.T.; Amdur, R.L.; Wormley, B.; O’Neill, F.A.; et al. Comprehensive Gene-Based Association Study of a Chromosome 20 Linked Region Implicates Novel Risk Loci for Depressive Symptoms in Psychotic Illness. PLoS ONE 2011, 6, e21440. [CrossRef]

42. Hamshere, M.L.; Schulze, T.G.; Schumacher, J.; Corvin, A.; Owen, M.J.; Jamra, R.A.; Propping, P.; Maier, W.; Diaz, G.O.Y.; Mayoral, F.; et al. Mood-incongruent psychosis in bipolar disorder: Conditional linkage analysis shows genome-wide suggestive linkage at 1q32.3, 7p13 and 20q13.31. Bipolar Disord. 2009, 11, 610-620. [CrossRef]

43. Erlangsen, A.; Appadurai, V.; Wang, Y.; Turecki, G.; Mors, O.; Werge, T.; Mortensen, P.B.; Starnawska, A.; Børglum, A.; Schork, A.; et al. Genetics of suicide attempts in individuals with and without mental disorders: A population-based genome-wide association study. Mol. Psychiatry 2018, 25, 2410-2421. [CrossRef]

44. Li, M.; Luo, X.-J.; Landén, M.; Bergen, S.; Hultman, C.M.; Li, X.; Zhang, W.; Yao, Y.-G.; Zhang, C.; Liu, J.; et al. Impact of a cis-associated gene expression SNP on chromosome 20q11.22 on bipolar disorder susceptibility, hippocampal structure and cognitive performance. Br. J. Psychiatry 2016, 208, 128-137. [CrossRef]

45. Peron, A.; Catusi, I.; Recalcati, M.P.; Calzari, L.; Larizza, L.; Vignoli, A.; Canevini, M.P. Ring Chromosome 20 Syndrome: Genetics, Clinical Characteristics, and Overlapping Phenotypes. Front. Neurol. 2020, 11, 1617. [CrossRef] [PubMed]

46. Kamath, B.M.; Thiel, B.D.; Gai, X.; Conlin, L.K.; Munoz, P.S.; Glessner, J.; Clark, D.; Warthen, D.M.; Shaikh, T.H.; Mihci, E.; et al. SNP array mapping of chromosome 20p deletions: Genotypes, phenotypes, and copy number variation. Hum. Mutat. 2009, 30, 371-378. [CrossRef] [PubMed]

47. Khattak, S.; Jan, M.; Warsi, S.; Khattak, S. Chromosome 20p Partial De Novo Duplication Identified in a Female Paediatric Patient with Characteristic Facial Dysmorphism and Behavioural Anomalies. Case Rep. Genet. 2020, 2020, 7093409. [CrossRef] [PubMed]

48. Hanafusa, H.; Morisada, N.; Ishida, Y.; Sakata, R.; Morita, K.; Miura, S.; Ye, M.J.; Yamamoto, T.; Okamoto, N.; Nozu, K.; et al. The smallest de novo 20q11.2 microdeletion causing intellectual disability and dysmorphic features. Hum. Genome Var. 2017, 4, 17050. [CrossRef] [PubMed]

49. Van Dijck, A.; Silfhout, A.T.V.-V.; Cappuyns, E.; van der Werf, I.M.; Mancini, G.M.; Tzschach, A.; Bernier, R.; Gozes, I.; Eichler, E.E.; Romano, C.; et al. Clinical Presentation of a Complex Neurodevelopmental Disorder Caused by Mutations in ADNP. Biol. Psychiatry 2018, 85, 287-297. [CrossRef] [PubMed]

50. Breen, M.S.; Garg, P.; Tang, L.; Mendonca, D.; Levy, T.; Barbosa, M.; Arnett, A.B.; Kurtz-Nelson, E.; Agolini, E.; Battaglia, A.; et al. Episignatures Stratifying Helsmoortel-Van Der Aa Syndrome Show Modest Correlation with Phenotype. Am. J. Hum. Genet. 2020, 107, 555-563. [CrossRef]

51. Bagyinszky, E.; Van Giau, V.; Youn, Y.C.; An, S.S.A.; Kim, S. Characterization of mutations in PRNP (prion) gene and their possible roles in neurodegenerative diseases. Neuropsychiatr. Dis. Treat. 2018, 14, 2067-2085. [CrossRef]

52. Griffith, C.B.; Vance, G.H.; Weaver, D.D. Phenotypic variability in trisomy 13 mosaicism: Two new patients and literature review. Am. J. Med. Genet. Part A 2009, 149A, 1346-1358. [CrossRef] [PubMed]

53. Pillinger, T.; D'Ambrosio, E.; McCutcheon, R.; Howes, O.D. Is psychosis a multisystem disorder? A meta-review of central nervous system, immune, cardiometabolic, and endocrine alterations in first-episode psychosis and perspective on potential models. Mol. Psychiatry 2018, 24, 776-794. [CrossRef] 